SPECIAL VOLUME

\title{
Geology of South and Southwest part of Uttar Pradesh and its Mineral Significance
}

\author{
G.K. Dinkar ${ }^{1,2}$, S.A. Farooqui ${ }^{2}$, Vinod K. Singh ${ }^{3, *}$, A.K. Verma ${ }^{1}$, Prashant Prabhat ${ }^{2,3}$ \\ ${ }^{1}$ Center of Advanced Study in Geology, University of Lucknow, Lucknow-226007, India, Email-gkdinkar@rediffmail.com \\ 2 Directorate of Geology and Mining Lucknow, Khanij Bhawan, Lucknow, Uttar Pradesh, India. \\ ${ }^{3}$ Department of Geology, Bundelkhand University, Jhansi-284128, India.
}

* Corresponding author : vinodksingh@bujhansi.ac.in

Tel.: +91-9415258237; fax: +91-5102321667

Received: Dec 17, 2018; Accepted: Feb 22, 2019.

DOI: 10.25299/jgeet.2019.4.2-2.2441

\begin{abstract}
The major part of Uttar Pradesh (U.P.) is covered by Gangatic alluvium in the north whereas the southern part is covered by peninsular terrain. The Peninsular part of Uttar Pradesh is covered by the rocks of Archean to Mesozoic age. This peninsular part covered by the Bundelkhand Craton, its nuclei mostly composed of Archean granitoids show heterogeneity in texture and composition, intruded by later phase of magmatic activity. The oldest unit, Bundelkhand Gneissic Complex (BGC) is exposed in the south and southwestern part of Uttar Pradesh, whereas the comparatively younger unit Dudhi Gneissic Complex (DGC) exposed in south and southestern part of Uttar Pradesh, which overlies by the Mahakoshal Group in Sonbhadra and Mirzapur district. The Mahrauni Group occurs as sliced unit between BGC and Bijawars and has the thrusted contact with BGC. The exposures of the rocks of Mahrauni Group are very scanty and exposed around Girar, Manpura and Rajaula areas of Mandawra block in Lalitpur district. The Bijawar Group is exposed around Sonrai area district Lalitpur of Uttar Pradesh. The rocks of Ajabgarh Group rocks are exposed in Mathura district. These groups- Bijawar, Mahakoshal and Ajabgarh are metasedimentary/metavolcanics unit and belong to Delhi Supergroup, which is capped by the sedimentary units of Vindhyan Supergroup, and exposed mainly in the southern part of Uttar Pradesh and a very few exposures in the west. The comparatively younger unit, Gondwanas is exposed only in south and southeastern part of U.P. mainly in Sonbhadra. The few exposures of Deccan Trap are also traced in Lalitpur district in the south of U.P. The northern part of U.P. is alluvium covered which belongs to Quaternary period. These quaternary sediments are classified in to older alluvium, newer alluvium and Aeolian younger sediments of upper Pleistocene-Holocene age. These sediments unconfomably lies over and undulating basement of the rocks of Delhi Supergroup of Proterozoic age. The older alluvium comprises fine grained, well compacted and more mature sediments occupying extensive stretches at relatively higher elevations. The Older Alluvium is classified in to Banda Older Alluvium and Vanarasi Older alluvium. Banda Older Alluvium (BOA) exposed around the rivers flowing. Varanasi Older Alluvium (VOA) exposed beyond the river basinal margins. The drainage pattern in region is subdendritic to dendritic type formed by hills and nalas flowing over the soil cover. Economically, the south and southwestern Uttar Pradesh is more significant for their economic mineral environment for the minerals of Iron, Gold, Diamond, Calcite, Platinum, Phasphorite, Clay, Graphite, Bauxite, Copper, Silica sand, Potash etc.
\end{abstract}

Keywords: Bundelkhand greenstone belt, Dudhi Gneissic Complex, Mahakoshal Group, Bijawar Group, Ajabgarh, Vindhyan Supergroup

\section{Introduction}

The state of Uttar Pradesh (U.P.) bounded by $23^{\circ} 52^{\prime \prime}$ to $31^{\circ} 25^{\prime \prime} \mathrm{N}$ latitude and $84^{\circ} 39^{\prime \prime}$ to $77^{\circ} 03^{\prime \prime} \mathrm{E}$ longitudes which comprise about $2,40,928 \mathrm{~km}^{2}$ area is made up of distinct rock types which extends from oldest Archean metamorphites to the youngest Quaternary alluvium. Statigraphically, this state is mostly covered by the alluvium of Ganga Plain which separates the Himalaya or Extra Peninsula and the Peninsula India. The Peninsular part of U.P. is exposing rocks of Archean to Mesozoic period. The Ganga, Yamuna, Ramganga, Gomti, Ken, Betwa and Ghaghra are the major rivers signify drainage of Uttar Pradesh. Medlicott (1859) was possibly the first to study the rocks of the Bundelkhand region. Hacket (1870) made geological report of Gwalior and its adjoining areas. Heron (1935) studied the rocks from various parts of Bundelkhand region and referred these rocks as "Bundelkhand Granite". Saxena (1957) interpreted the trends of mineral lineation as suggestive of direction of flow of granitic fluids. Jhingran (1958) suggested that the pink granite is younger than the grey ones. On the basis of grain size, colour of feldspar and presence or absence of ferromagnesian minerals, he distinguished ten types of granites within the great batholithic massif. He also reported gneisses, quartz-reefs, basic dykes and tuffaceous serpentinite rocks in the craton. Saxena (1961) stated that the Bundelkhand granitic activity as an 
equivalent to the Closepet granite of Dharwar Craton of South India. Prakash et al. (1975) stated that the Mehrauni Group rocks are oldest unit of the southwestern part of Bundelkhand massif. Mishra and Sharma (1975) made a systematic study of the stratigraphic setting of the Bundelkhand complex. Sharma (1982) made a detailed lithostratigraphic, structural and petrological study of the Kuraicha Formation and Bundelkhand Group. Bhattacharya (1985) estimated tectonic strain for the rocks of the Bundelkhand massif and has shown that the mineralogical behaviour of the rocks has controlled the deformation patterns of the massif. Basu (1986) carried out extensive field investigations and mapped the entire area of the Bundelkhand Craton. Bhattacharya (1986) developed a semi-quantitative method for identifying different fold episodes of deformed terrains. Sarkar et al. $(1989,1995,1997)$ presented a detailed account of the geochronology and petrology of various rock types of the Bundel khand complex. Basu (2001) presented a model for the evolution of the continental crust, considering the geological, structural, geophysical data, and mineralization aspects, of the Bundelkhand Craton.

Pati and Raju (2001) studied petrochemistry of the pillowed metabasalts of Bijawar Group, as exposed in a few parts of the Sonrai area in Lalitpur District of Uttar Pradesh. Mondal et al. (2002) dated the gneissic and granitiod rocks of the Bundelkhand massif by ion-microprobe ${ }^{205} \mathrm{~Pb} /{ }^{206} \mathrm{~Pb}$ (Zircon age) methods. Farooqui and Singh (2006)and Farooqui and Singh (2010), Kaur et al. (2014, 2016); Verma et al., (2016); Saha et al. (2016); and Nasipuri et al. (2019) discuss the geochronological aspects of Bundelkhand granitoids in detail. Bhattacharya and Singh (2013) described the Proterozoic crustal scale shearing in the Bundelkhand massif with special reference to quartz reefs. Recently Singh and Slabunov (2015a, 2015b, 2016), Slabunov et al. (2017), and Slabunov and Singh (2018) discussed the geology and geochronology of the supracrustal rocks of Bundelkhand Craton and first to establish two greenstone complex i.e., Central and Southern Bundelkhand. Further studies suggest that the entire area was subject to two major phases of sedimentary-volcanic process before regional granitisation during the Archean. Granitisation, in preferred tectonic block, led to the development of an intra-cratonic belt controlled between lineaments, within which the younger Bijawar-Vindhyan basins developed. The rocks of the Archean basement complex and the overlying sedimentary sequences in the Bundelkhand Craton occur in southern Uttar Pradesh and adjoining Madhya Pradesh, within which broad but distinct stratigraphic units are recognized and classified (Fig. 1) and discussed in detail in following section.

\section{Geology of Southern part of Uttar Pradesh and adjoining area}

The Peninsular part of Uttar Pradesh is covered by the rocks of Areachen to Mesozoic ages (Fig. 1). The hard rocks are mainly igneous and metamorphic rocks and are exposed as isolated hills. The basement of the Peninsular belongs to Bundelkhand granitoids intruded by later phase of magmatic activity. The rocks exposed in the southwest and south part of state are dominantly granitic, consist Bundelkhand Craton and those in the Sonbhadra area in the east are dominantly gneissic rocks, comprise Mahakoshal belt (Fig. 1).

The Bundelkhand Craton mostly contains a wide variety of plutonic and hypabyssal rocks dominated by porphyritic granite of several generations, gneisses, migmatites, and lucogranites (Geological Survey of India, 2012). Migmatites, different types of granite, basic intrusive dykes and quartz reefs have been identified and assigned to various types. It is generally agreed that the enclaves of metabasics and metasedimentary are older than the granitoids. The Bundelkhand granitoids display heterogeneity in texture and composition and are pegmatitic in some places (Dinkar, 2016; Dinkar et al., 2018). The detailed geology of central Bundelkhand greenstone complex is given by Singh and Slabunov (2015a) and Slabunov and Singh (2018), so we don't discuss here. The southern Bundelkhand greenstone complex exposures of the rocks belonging to Mehroni Group are very scantly and can be observed around Girar, Manpura and Rajaula areas in Mandawra block of Lalitpur (Prakash et al., 1975; Singh and Slabunov, 2016; Slabunov et al., 2017; Dinkar et al., 2018 and references therein).

In Sidhi (Son valley) area, the older metamorphics and granite gneiss are exposed as a linear belt south of Mahakoshal belt and in Rihand reservoir area bordering Mirzapur District, Uttar Pradesh. The gneissic complex associated with high grade meta-sedimentary and meta-volcanics including mafic and ultramafic schist. These include sillimanite-garnet gneiss, garnet-sillimanite-corundum schist, staurolite-garnet-biotite schist, garnetiferous grunerite-magnetite quartzite, quartz sericite schist, quartzite, marble and calc-silicate rocks, talcchlorite schist, amphibolites and hornblende granulite (Geological Survey of India, 2012).

The Dudhi Gneissic Complex (DGC) composed of mainly granitic gneiss, migmatites, and nonfoliated massive granite with enclaves of metamorphites and veins of pegmatite, aplite and quartz (Geological Survey of India, 2012). The rocks of this group are exposed in Mirzapur and Sonbhadra areas in Uttar Pradesh.

The Mahrauni Group occurs as sliced unit between BGC and Bijawars and has the thrusted contact with BGC in southern Lalitpur. The exposures of the rocks of Mahrauni Group are very scanty and exposed around Girar, Manpura and Rajaula areas of Mandawra block in Lalitpur district.

The rocks of Mahakoshal Group in the Uttar Pradesh are the eastward extension of similar rocks of Madhya Pradesh inferred to have Paleoproterozoic age to the group includes metasediments with interlayered metavolcanics and granitic bodies intruding it (Geological Survey of India, 2012). Roy and Devarajan (2000) classified this group into three formations. The youngest one is Dudhmaniya Formation composed of impersistent Banded Iron Formation, chlorite phyllite and greywacke underlain by an argillite-predominently facies- the Parsoi Formation, and oldest one is Agori Formation characterized by the argillite-arenite facies with chemogenic rocks (BIF). Parsoi Formation characterized by andalusite is developed in the phyllite. The basal part 
of Agori Formation is characterised by proliferation of the basic and ultrabasic volcanic rocks. The upper part of the Agori Formation contains BIF, phyllite, acid volcanic and calcareous and chert bands.

The Bijawar Group (metasedimentary sequence) characterized by ferruginous quartzite, carbonate, phosphorite, sandstone and tuffaceous rocks rest over unconformably on the southern part of Bundelkhand Craton. The rocks of this group are exposed in Sonrai area in the southern part of Lalitpur district. The classification of the Bijawar group into Sonari Formation, Solda Formation and Kurrat flow is in ascending order. The Sonari Formation is consisting of carbonate, arenite, argillite sequence and phosphorites horizons. The Solda Formation characterized by ferruginous quartzite, shale and tuffaceous rocks, is the youngest formation (Absar et al., 2009).

The small exposures of Ajabgarh Group characterized by purple and white quartzite interbedded with phyllite and slate occur in Mathura district. This sequence traversed by quartz veins is grouped under Barsana Formation. The Barsana Formation in the Uttar Pradesh is northeastward extension of the Ajabgarh Group of Paleo- to Meso-proterozoic age.

The Bundelkhand Craton is capped by the sedimentary units of Vindhyan Supergroup in southern and western side. The rocks of this unit occur as mounds and small hillocks. These are structurally controlled by E-W and NE-SW trending lineaments. This supergroup is subdivided unconformably into a lower sequence (Semri Group) and an upper sequence (Kaimur, Rewa and Bhander Groups).

The Semri Group includes carbonate, tuff, green silicious shale and minor glauconitic sandstone and dolomitic limestone, with conglomerate bands in the basal part. The shale sequence is composed of alternate green bands of shale, mudstone and siltstone. This is exposed along the margins of the basin and is well developed in the Son valley, Rewa and Katni area and along the northern limit of the Vindhyan terrain in the Bundelkhand region in part of the Satna, Panna, Chhatarpur and Damoh district of Madhya Pradesh (Ramakrishnan and Vaidyanadhan, 2010).

The Kaimur Group are consists of sandstone and overlying quartz arenite containing silica sand as lenses in the arenite. These conglomerate lenses occur in the basal part of the sequence. The Kaimur Sandstone transgresses the Semri rocks towards the north and west directly overlies the Bundelkhand Granite and Bijawar rocks. However the southern margin, the contact between Kaimur and underlying Semri groups appears to be without any break in sedimentation, although, a few conglomerate bands are recorded.

The overlying sequence of the Rewa Group consist thick alternating sequence of argillaceous lithounits with interbedded diamondiferous conglomerate horizons conformably overlying the Kaimur rocks with a gradational contact. This Group is divided into Panna shale, Lower Rewa Sandstone, Jhiri Shale and Upper Rewa Sandstone. Generally, limestone is absent except for a restricted occurrence in the lower most Paisuri Formation of the group and occurs mainly in northern part of Satna district and further east.

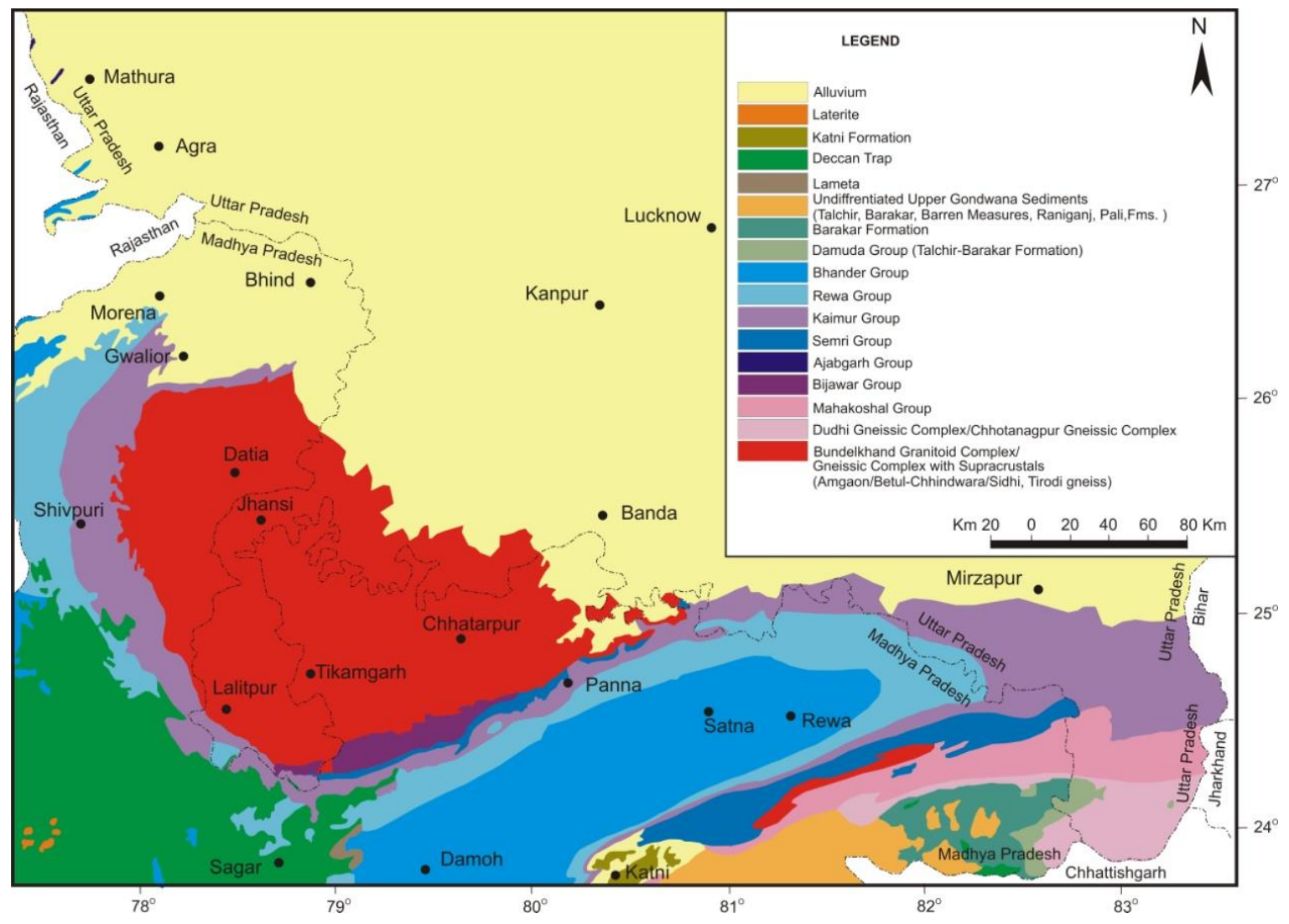

Fig.1: Geological map of southern part of Uttar Pradesh and adjoining area (modified after Geological Survey of India, 2012). 
Bhander Group occupies the central part of the basin in Rewa, Satna, Damoh, Sagar and Bhopal. The Bhander Group chiefly represents a basal argillaceous unit passing into arenaceous units and algal stromatolitic calcareous unit (Satna-Rewa-Nagod-Amanganj-hatta area.) Non-stromatolitic limestone is recorded in Bhopal. This Group has been divided into Ganurgarh Shale, Nagod Limestone, Sirbu Shale and Maihar (Upper Bhander) Sandstone. The Vindhyan Group is unconformably overlain the Bijawars.

A few outcrops of Lameta Bedds and Deccan Trap occur in the southern part this state. One outcrop of Deccan Trap relatively large in size trending in almost $\mathrm{N}-\mathrm{S}$. These outcrops are smaller in size and extend for a few tens of meters only. The Deccan Trap occurs as flat cap rocks in the area. The Deccan Trap is mainly constituted of basaltic rocks. Most of the basaltic rocks show highly weathered and irregular surfaces as well as lateritic soil and black alluvium soil cover. The presence of characteristic black cotton soil cover marked by extensive gully development confirms the occurrence of volcanic 'traps' overlie the Bundelkhand Granitoids. The detailed stratigraphic successions of southern part of Uttar Pradesh are summarized in table 1.

Table 1: Generalized Stratigraphic Succession of Southern part of Uttar Pradesh (after Geological Survey of India, 2012).

\begin{tabular}{|c|c|c|c|}
\hline Sr. Gr. & Group & Formation & Member/Lithology \\
\hline & \multirow{3}{*}{$\begin{array}{l}\text { Newer } \\
\text { Alluvium }\end{array}$} & $\begin{array}{l}\text { Channel Alluvium/ } \\
\text { Colluvium }\end{array}$ & $\begin{array}{l}\text { Grey micaceous fine to coarse grained sand, silt } \\
\text { and clay }\end{array}$ \\
\hline & & Terrace Alluvium & $\begin{array}{l}\text { Cyclic sequence of grey micaceous sand, silt and } \\
\text { clay }\end{array}$ \\
\hline & & $\begin{array}{l}\text { Fan Alluvium/ Bhat Alluvium/ } \\
\text { Ramnagar Alluvium }\end{array}$ & $\begin{array}{l}\text { Light grey to khaki, silt-clay and cross bedded } \\
\text { fine sand with gravel and pebbles }\end{array}$ \\
\hline & \multirow[t]{2}{*}{ Older Alluvium } & Varanasi Alluvium & $\begin{array}{l}\text { Polycyclic sequence of oxidized khaki to brown } \\
\text { silt-clay with kankar and brown to grey fine to } \\
\text { medium micaceous sand gravel (divisible into } \\
\text { silt-clay sandy and rudaceous facies) }\end{array}$ \\
\hline & & Banda Alluvium & $\begin{array}{l}\text { Reddish to deep brown quartzo-feldspathic sand } \\
\text { with gravel lenses, silt and clay }\end{array}$ \\
\hline & & Laterite & $\begin{array}{l}\text { Gravel and pebble of laterite and bauxite with } \\
\text { deep cherry red to brownish black lithomarge } \\
\text { clay }\end{array}$ \\
\hline \multicolumn{3}{|c|}{ Deccan Trap } & Basic rocks, dolerite and basalts \\
\hline \multicolumn{3}{|c|}{ Lameta Bed } & Silty shale and clay \\
\hline \multirow{3}{*}{ Gondwana } & \multirow{3}{*}{ Damuda } & Barakar & $\begin{array}{l}\text { Coarse, ferruginous sandstone intercalated with } \\
\text { coal seams and shale }\end{array}$ \\
\hline & & Talchir & Green shale and diamictite \\
\hline & & Boulder Bed & Green shale, boulder shale and diamictite \\
\hline \multicolumn{3}{|c|}{ Post Delhi Intrusive } & $\begin{array}{l}\text { Granite and granite gneiss, pegmatite, quartz vein } \\
\text { and amphibolite }\end{array}$ \\
\hline \multirow{9}{*}{ Vindhyan } & \multirow{5}{*}{ Bhander } & $\begin{array}{l}\text { Maihar/ Tantpur } \equiv \text { Upper } \\
\text { Bhander Sandstone }\end{array}$ & $\begin{array}{l}\text { White to purple quartz arenite, medium to fine } \\
\text { grained purple and reddish spotted and } \\
\text { laminated sandstone with intermitted partings of } \\
\text { shale and siltstone and occasional shale and } \\
\text { pebble conglomerate }\end{array}$ \\
\hline & & Sirbu Shale & $\begin{array}{l}\text { Alternating splintery, ferruginous chocolate } \\
\text { shale, greenish shale }\end{array}$ \\
\hline & & Lower Bhander Sandstone & Sandstone with subordinate siltstone \\
\hline & & $\begin{array}{l}\text { Nagodi/Lakheri } \equiv \text { Upper } \\
\text { Bhander Sandstone }\end{array}$ & $\begin{array}{l}\text { Grey-greyish blue stromatolite limestone with } \\
\text { greenish grey shale intercalation }\end{array}$ \\
\hline & & Ganurgarh $\equiv$ Simrawal Shale & $\begin{array}{l}\text { Brick red to purple brown evenly bedded shale } \\
\text { with gypsum partings }\end{array}$ \\
\hline & \multirow[t]{4}{*}{ Rewa } & $\begin{array}{l}\text { Taragarh/ Govindgarh; } \\
\text { Ghadara; Chauri=Upper Rewa } \\
\text { Jhiri Shale/Jhiri } \equiv \text { Kokah Shale }\end{array}$ & $\begin{array}{l}\text { Reddish brown to purple massive current bedded } \\
\text { sandstone } \\
\text { Greenish grey shale with siltstone and sandstone } \\
\text { interbeds }\end{array}$ \\
\hline & & $\begin{array}{l}\text { Itwa/ Asan/ Kopar } \equiv \text { Lower } \\
\text { Rewa sandstone }\end{array}$ & $\begin{array}{l}\text { Greenish glauconitic medium to fine grained } \\
\text { current bedded sandstone with diamondiferous } \\
\text { conglomerate }\end{array}$ \\
\hline & & Panna & $\begin{array}{l}\text { Greenish grey white to purple shale and quartz } \\
\text { arenite }\end{array}$ \\
\hline & & $\begin{array}{l}\text { Dhandraul/Drummondganj } \equiv \\
\text { Mangesar/ Bhouri/ Dudauni } \\
\text { Sandstone }\end{array}$ & $\begin{array}{l}\text { Milky white, compact, medium to fine grained } \\
\text { sandstone and orthoquartzite }\end{array}$ \\
\hline
\end{tabular}




\begin{tabular}{|c|c|c|c|}
\hline & & $\begin{array}{l}\text { Scarp } \equiv \text { Mangesar/ } \\
\text { Bhouri/ Dudauni } \\
\text { Sandstone }\end{array}$ & $\begin{array}{l}\text { Red, pink, compact, blocky sandstone, khaki and } \\
\text { greenish grey, micaceous sandstone and siltstone }\end{array}$ \\
\hline & & Bijaigarh & $\begin{array}{l}\text { Grey micaceous siltstone, red and yellow ochre } \\
\text { shale and siltstone, black carbonaceous shale and } \\
\text { ferruginous sandstone }\end{array}$ \\
\hline & & Markundi & $\begin{array}{l}\text { Light greyish white, medium to fine grained } \\
\text { silicified sandstone and arkosicsandstone }\end{array}$ \\
\hline & Kaimur & Susnai breccia $\equiv$ Koh & $\begin{array}{l}\text { Autoclastic breccia with angular fragment of } \\
\text { porcellainitic shale interbedded in gritty to sandy } \\
\text { matrix }\end{array}$ \\
\hline & & Ghurma & $\begin{array}{l}\text { Black carbonaceous, micaceous, yellow braown } \\
\text { and light grey porcellainitic shale and thin bands } \\
\text { of sideritic ironstone }\end{array}$ \\
\hline & & Ghaghar $\equiv$ Sasaram & Coarse to medium grained pinkish sandstone \\
\hline & & & $\begin{array}{l}\text { Alaur Member: Thin bedded limestone with } \\
\text { argillaceous and cherty intercalations }\end{array}$ \\
\hline & & $\begin{array}{l}\text { Rohtasgarh } \equiv \text { Tirohan/ } \\
\text { breccia }\end{array}$ & $\begin{array}{l}\text { Rudauli Member: Fine laminated black } \\
\text { porcellainitic shale with cherty limestone nodule }\end{array}$ \\
\hline & & & $\begin{array}{l}\text { Kurail Member: Very fine grained limestone, } \\
\text { dolomitic at base with sand and mud dykes }\end{array}$ \\
\hline Vindhvan & Semri & $\begin{array}{l}\text { Basuhari } \equiv \text { Glauconitic, } \\
\text { Rampur Pandwafall Sandstone }\end{array}$ & $\begin{array}{l}\text { Khandura Member: Fine laminated flaggy } \\
\text { greenish shale and porcellainitic shale } \\
\text { Mungadih Member: Greenish glauconitic } \\
\text { medium grained sandstone }\end{array}$ \\
\hline vinumyan & & $\begin{array}{l}\text { Bargawan } \equiv \text { Fawn and } \\
\text { Salkhan Limestone }\end{array}$ & $\begin{array}{l}\text { Nauka Tola Member: Fawn to yellow brown } \\
\text { cherty dolomitic limestone }\end{array}$ \\
\hline & & $\begin{array}{l}\text { Kheinjua } \equiv \text { Koldaha Shale, } \\
\text { Olive Shale }\end{array}$ & $\begin{array}{l}\text { Olive to greenish grey, khaki, splintery shale with } \\
\text { calcareous interbeds and partings }\end{array}$ \\
\hline & & Chopan $\equiv$ Deonar & $\begin{array}{l}\text { Light grey, greenish porcellainitic shales } \\
\text { agglomeratic beds and arkosic sandstone }\end{array}$ \\
\hline & & Kajrahat & $\begin{array}{l}\text { Siliceous, cherty, dolomitic limestone, blocky and } \\
\text { slabby limestone with argillite interbeds }\end{array}$ \\
\hline & & Arangi & $\begin{array}{l}\text { leached purplish porcellainitic shale and black } \\
\text { calcareous shales }\end{array}$ \\
\hline & & $\begin{array}{l}\text { Phaterwar (三 Basal } \\
\text { Conglomerate, Deolond) }\end{array}$ & $\begin{array}{l}\text { Gritty to pebbly sandstone, medium grained } \\
\text { sandstone, siltstone and basal conglomerate }\end{array}$ \\
\hline & & & Hard compact sandstone \\
\hline & & Panchperi & Purple thin laminated shale \\
\hline & $\begin{array}{l}\text { Jungel } \\
\text { (West of }\end{array}$ & & $\begin{array}{l}\text { Conglomerate and sandstone with impersistent } \\
\text { shale }\end{array}$ \\
\hline & Son River) & Baharadand & $\begin{array}{l}\text { Basal, dolerite, tuff, aggolomerate and } \\
\text { serpentinite }\end{array}$ \\
\hline & & Tasing & $\begin{array}{l}\text { Slate, phyllite, minor schist with quartzite } \\
\text { laminations }\end{array}$ \\
\hline & Ajabgarh & Asarwas & $\begin{array}{l}\text { Phyllite, slate, limestone, quartzite intercalated } \\
\text { with phyllite and schist }\end{array}$ \\
\hline & & Thanagazi & Carbonaceous phyllite and tuff \\
\hline & & Deota-Dantal & Brecciated quartzite, minor phyllite and schist \\
\hline & & Solda & $\begin{array}{l}\text { Ferruginous quartzite and shale, BHQ, chloritic } \\
\text { schist and cal careous sandstone }\end{array}$ \\
\hline & & Sonari & $\begin{array}{l}\text { Calcareous sandstone, grey shale, grit with lenses } \\
\text { of phosphoriteand banded sulphide }\end{array}$ \\
\hline Delhi & Bıjawar & Kurrat Lava & Basaltic flows of tholeiitic composition \\
\hline & & Dudhamaniya & $\begin{array}{l}\text { Phyllite, quartzite, shale/slate, mica schist with } \\
\text { younger intrusives }\end{array}$ \\
\hline & Mahakoshal & Parsoi & $\begin{array}{l}\text { Variegated phyllite, greywacke, quartzite, } \\
\text { metabasics and dolerite dykes and quartz vein }\end{array}$ \\
\hline & & Agori & $\begin{array}{l}\text { Shale, siltstone, sandstone, BIF, basic and } \\
\text { ultrabasic rocks }\end{array}$ \\
\hline Dudhi Granitoid & $\begin{array}{l}\text { Jhirgadandi, } \\
\text { and Sirpalia }\end{array}$ & $\begin{array}{l}\text { aghisoti - Dumar, Asnadohar } \\
\text { iranite }\end{array}$ & $\begin{array}{l}\text { Two mica granite, diorite, porphyritic granite, } \\
\text { mesocratic granite and pink leucogranite }\end{array}$ \\
\hline Complex & Dudhi Granit & & Porphyoblastic Gneiss \\
\hline & Dudhi Gneis & & Banded gneiss, migmatite and biotite gneiss \\
\hline & Basic-Ultrab & sic Intrusives & $\begin{array}{l}\text { Dolerite, lamprophyre, olivine basalt, kersanite, } \\
\text { gabbro }\end{array}$ \\
\hline
\end{tabular}




\begin{tabular}{|l|l|l|}
\hline \multirow{4}{*}{$\begin{array}{l}\text { Bundelkhand } \\
\text { Granitoids }\end{array}$} & Acid Intrusives & $\begin{array}{l}\text { Aplite, pegmatite, quartzofeldspathic vein, quartz } \\
\text { reef/ vein, pyrophyllite }\end{array}$ \\
\cline { 2 - 3 } & Porphyries & Granite, rhyolite, diorite, dacite \\
\cline { 2 - 3 } & Granite & $\begin{array}{l}\text { Coarse grained; Medium grained; and Fine } \\
\text { grained grey, and pink granite. } \\
\text { Porphyritic coarse grained and Porphyritic grey, } \\
\text { and pink granite. } \\
\text { Fine grained and Medium grained leucogranite. }\end{array}$ \\
\cline { 2 - 3 } & Gneisses & $\begin{array}{l}\text { Augen gneiss, granite gneiss, porphyritic granite } \\
\text { gneiss, migmatite. }\end{array}$ \\
\hline
\end{tabular}

\section{Geology of Soil Covers of Uttar Pradesh}

Geologically, Uttar Pradesh is covered by alluvium in the north whereas the southern part is covered by peninsular terrain. The alluvium of Gangatic plain extends from Aravalli-Delhi Ridge in the west to Rajmahal hills in the east. This alluvium sediment belongs to Holocene period. The Ganga foredeep sediments extend much to south of depositional boundary of the Siwalik Foredeep and rest over the Cratonic rocks of Precambrian age. The peninsular uplands also contribute to a significant volume of sediments. The different lithology coupled with depth of weathering of these two regions is reflected in the lithology of Holocene sediments, is mainly dominated by VOA sediments exposed beyond the river basinal areas and BOA sediments exposed around the rivers flowing.

The sediments of VOA consisting of polycyclic sequences of brownish silt clay and micaceous sand with small calcrete horizons overlies the BOA sediments. The sediments of Varanasi alluvium were derived from Himalayan provenance. These sediments show progressively finer characteristics away from provenance. Banda Older Alluvium is exposed in the area south of the Yamuna River bordering the Peninsular Upland and it rests over the Precambrian rocks. These older alluvium comprises finer grained, well compacted and more mature sediments occupying extensive stretches at relatively higher elevations. These sediments, related to some earlier fluvial episodes, have been at most places stabilized by vegetation and majority of the badlands are sculptured within it. These sediments characteristically display red brown colour and are richer in ferruginous content.

The drainage pattern in the region is subdendritic to dendritic type formed by hills and nalas flowing over the soil cover. The southern part of the state mainly drained by Betwa a tributary of Yamuna river basin. Betwa is feeding by its tributaries Dhasan, Kane river etc.

\section{Mineral significance in southern part of Uttar Pradesh}

The minerals found in Uttar Pradesh include limestone, dolomite, glass-sand, marble, bauxite, non-plastic fireclay, and Uranium. Besides, Barytes and andalusite are found in the districts of Mirzapur and Sonbhadra. Sand-stone, pebbles, reh, salt punter, maurang, sand and other minor minerals are also found in the State. The following types of minerals which occur in the Uttar Pradesh (Geological Survey of India, 2012) discussed below. Iron: An outcrop of Banded Hematite Quartzite (BHQ) in the Berwar Formation of the Mehroni Group found in the west of Dhasan River between Berwar and Girar. The lithology comprises meta-sedimentary rocks associated with metavolcanics. Detailed work by Directorate of Geology and M ining,U.P. In the Solda area of Lalitpur district iron ore is associated with the rocks of Bijawar Group and iron ore occurs in small pockets of enriched secondary crystalline haematite within Bijawar group of rocks around Sonrai area in Lalitpur district.

In the Sonbhadra district, south of Dudhi near Migrarasni, the BHQ contains iron ore with pockets of rich specularite occurs within Mahakoshal Group around Parsoi area.

Diamond: In Sonbhadra, Jungel Valley exposes volcanic suite of rocks consisting of different types of basaltic flow agglomerates intruded by ultramafic plugs. Detail exploration has revealed five plugs in the area. Two diamonds have been found from one of the plugs at a depth of $4.5 \mathrm{~m}$. In Banda, around Kalinger three diamond crystals were recovered from the palaeo-channel of Baghein River, during the exploration for placer diamonds by Directorate of Geology and Mining, U.P.

Gold: Placer gold is reported from the Sona Nadi near Kalagarh in Nagina Tehsil of Bijnor as reported by Directorate of Geology and Mining, U.P. In Gonda, Auriferous gravel beds occur in channel bars, point bars and younger terraces of Dara, Dhobha, Kowali and Bhambher River around Jhorwa. In Barabanki, Beharaich, Faizabad, Ambedker Nagar auriferous gravel beds occur in channel bars, point bars and younger terraces of sand in Ghagara River as reported by Directorate of Geology and Mining, U.P. In Lalitpur Placer gold is found in second and third terraces along the Sukharwah River around Patha as reported by Directorate of Geology and Mining, U.P. and also in Dhasan River in Girar.

Primary gold is reported in Lalitpur, from quartzofeldspathic and quartz veins associated with mafic dykes in the BGC and Banded Iron Formation (BIF) around Girar as reported by Directorate of Geology and Mining, U.P. Silicified/cherty bands and smoky quartz veins occurring at Girar and Bhikampur have gold bearing. In Sonbhadra, gold associated with rocks of Mahakoshal Group, represented by the metamorphic volcanic rocks inter-bedded with phyllite, lenticular chert and limestone, Banded Iron Formation (BIF), quartzite and metagreywacke. 
Platinum: In Lalitpur, Platinum and palladium mineralization is recorded in the eastern part of Mandawra as reported by Directorate of Geology and Mining, U.P.

Antimony: In Sonbhadra, Antimony values have reported from Amriniya area. Mineralization is observed in the form of veins and pockets of stibnite, associated with the quartz vein in Dudhkhamba and Dandakhan localities of Mahakoshal area.

Arsenic: In Sonbhadra, Arsenopyrite and scorodite mineral occur in association with the gold occurrences in the rocks of Mahakoshal Group around Gulaldih, Bihwa, Amriniya and Parsoi.

Copper: In Lalitpur, the mineralization of copper occurs around Sonrai area. The mineralization is confined to a zone of black shale, chert and breccia within the Bijawar Group as reported by Directorate of Geology and Mining, U.P. In Sonbhadra, the mineralization is associated with the Fawn limestone of Semri Group and the Mahakoshal Group.

Bauxite: In Chittrakut, the Directorate of Geology and Mining, U.P., explored bauxite deposit in Rajahuan area and its surrounding. In this area, the bauxite horizon is 2-5 m thick. In Lalitpur, bauxite occurring as capping over the Dhandraul Quartzite (Kaimur Group of the Vindhyan Supergroup) is located in Pathrai, north of Imlia Tal, south of Bigori area. In Varanasi, bauxite occurrence has been reported in laterite capping in Chandraprabha area. The laterite profile developed over the rocks of Kaimur Group is marked by ferruginous quartzite at base, clay and lithomarge in the middle part and laterite with bauxite horizon at top.

Molybdenum: In Sonbhadra, the tungsten mineralization occurs to north of Wyndhamganj, Sonbhadra. The mineralization occurs in the rocks of the Parsoi Formation of Mahakoshal Group and also within the intrusive granite and quartz veins. In Hamirpur, geochemical survey carried out by Geological Survey of India reported tungsten in Bilkhi of Hamirpur District.

Agate: In Banda, it is found in Quaternary gravels of Ken River. Moss agate contains small dendrites made up of manganese/iron-oxide.

Andalusite: In Sonbhadra, Andal usite occurrences have been located near Wyndhamganj and Bagarwa. It occurs as porphyroblasts in phyllite of Parsoi Formation, mainly confined to its contact with the granite and also in quartz and pegmatite veins traversing the phyllite.

Calcite: In Sonbhadra, a small lenticular occurrence of calcite is known within the rocks of Sidhi Group, near Parsoi.

Clay: In Banda, lithomargic clay occurs in lateritic profile in Lakhanpur area. The lateritic profile is developed over the rocks of the Vindhyan Supergroup. In Sonbhadra, clay pockets are associated with rocks of the Gondwana Supergroup, Vindhyan Supergroup and Dudhi Gneissic Complex in different areas. In Varanasi, clay is associated with the bauxite profile in Chandraprabha area at Lorha. Bauxite profile is developed over the Dhandraul Sandstone of the Vindhyan Supergroup.

Feldspar: In Jhansi district of the Uttar Pradesh, feldspar bearing pegmatite veins are intrusive into the Bundelkhand Granitoids occurs near Bijauli.

Graphite: In Hamirpur, a lenticular body of graphite occurs in the Bundelkhand Granitoids near Pathnauri and Rath as reported by Directorate of Geology and Mining, U.P.

Gypsum: In Jhansi, gypsum occurrences are similar to those of Hamirpur District. Selenite is reported from Gonti, Gokal, Dhanora, Parsua, Siya and Malheta areas.

Limestone/Dolomite: In Banda region, Tirohan Limestone, a dolomitic limestone is exposed along the base of Vindhyan scarp and is overlain by the quartzite and sandstone of the Semri Group of Vindhyan Supergroup. The limestone has invariable a high $\mathrm{MgO}$ content and is therefore, unsuitable for manufacture of cement. In Sonbhadra, Limestone bands occur within the Semri Group of Vindhyan Supergroup. The deposits of limestone are confined to Kajrahat and Rohtas Formation of Semri Group as reported by Directorate of Geology and Mining, U.P.

Marble: In Sonbhadra, the deposits occur around Kauria hill is the extension of Ningha deposit. This deposit is associated with the rocks of Agori formation of Mahakoshal Group (Geological Survey of India, 2012). The lithology of Agori Formatiom is completely sedimentary in nature with basic and ultrabasic rocks, whereas the marble is metamorphic in nature. And the rocks of Agori Formation do not attained the metamorphic grade, so on the basis of metamorphic grade it can be said that this marble will not be of Agori formation. As per GSI, 2012 The marble unit occurs in Golwa - Gangutana Formation of Alwar Group in Stratigraphy, but this Alwar Group is not exposed in Sonbhadra. Hence, it can be said that this marble can belongs of Alwar Group of Delhi Supergroup?

Phosphorite: In Lalitpur, rock phosphates occur near Sonrai and Jetupura area. The phosphorite is associated with the rocks of Jamini and Rohni member of the Sonrai Formation. In Sonbhadra, incidences of phosphorite are also reported from stromatolitic limestone bands of the Kajrahat limestone Formation around Bari and Sindhuria in Sonbhadra district.

Potash: In Banda, glauconite bearing Panna Shale of Rewa Group is exposed around Patin, Itwah and Kumsi. In Sonbhadra, the potash bearing glauconite is associated with shale and sandstone of Kheinjua Formation of the Semri Group and exposed around Newari and Basuhari area.

Pyrophyllite and Diaspore: In Jhansi, the deposits are located around Palar, Gorhari and Bawal Tanda. In Lalitpur, Pyrophyllite and Daispore are occurring in several localities near Rajghat dam. In Hamirpur, the pyrophyllite and diaspore deposits found at Gaurhari, Pahari, Garhi and Tori area. 
Silica Sand: In Prayagraj (Allahabad), Silica sand occurs around Shankargarh. It is associated with Dhandraul Sandstone of the Kaimur Group. Pratappur Member of the Dhandraul Sandstone contains thick silica sand horizon. In Banda, silica sand deposit occurs around Baragarh. This deposit is an extension of the Shankargarh deposit of Allahabad District. In Chandauli, Silica sand deposits also reported from several localities. The silica sand derived from the weathering of Dhandhraul Sandstone of the Kaimur Group.

Sillimanite: In Sonbhadra, Sillimanite mineralization occurs in Chipia village in quartz biotite schist.

Uranium: In Lalitpur, the Uranium in the form of coffinite occurs with hard bitumen within the zones of decollement, as well as in the brecciated Bandai Sandstone of Sonrai Fromation. In Sonbhadra, Surface indicators of uranium mineralisation associated with ferruginous brecciated rocks is traceable intermittently, exposed along the Jamual-Markundi, fault at tectonic contact of Neo- to Meso-proterozoic Vindhyan Supergroup and Paleoproterozoic Mahakoshal Group between Gurdha and Mohariya, Sonbhadra district.

\section{Acknowledgements}

GKD extends his thanks to the Director, Directorate of Geology and Mining, U.P., for granting him permission to carry out this work as part of his doctorate thesis. GKD also express our sincere thanks to the Head, Centre of Advanced Study in Geology, University of Lucknow, for providing working facilities and valuable encouragement.

\section{References}

Absar, N., Raza, M., Roy, M., Naqvi, S.M., Roy, A.K., 2009. Composition and weathering conditions of Paleoproterozoic upper crust of Bundelkhand craton, Central India: records from geochemistry of clastic sediments of 1.9 Ga Gwalior Group. Precambrian Research 168, 313-329.

Basu, A.K., 1986. Geology of parts of the Bundelkhand Granite massif Central India: Record Geol. Sur. of India 117, 61-124.

Basu, A.K., 2001. Some Characteristics of the Precambrian Crust in the Northern part of Central India. Geol. Surv. Ind. Spl. No. $55,182-204$.

Bhattacharya, A.R., 1985. Some unusual strain relations in elliptically deformed xenoliths and feldspar porphyroblasts. Zeitsch. Geol. Wissen. Berlin, 13(6), 689-697.

Bhattacharya, A.R., 1986. Wavelength-amplitude characteristics of polyphase folds in the Precambrian Bundelkhand Complex. Tectonophysics, 128 (1-2), 121-125.

Bhattacharya, A.R., Singh, S.P., 2013. Proterozoic Crustal Scale Shearing in the Bundelkhand Massif with Special Reference to Quartz Reefs. J. Geol. Soc. Ind., 82, 474-484.

Dinkar, G.K., 2016. Deformation pattern of the rocks exposed around Sonrai, district Lalitpur, Uttar Pradesh. University of Lucknow, Lucknow, Unpublished Ph.D. Thesis.

Dinkar, G.K., Bhattacharya, A.R., Verma, A.K., Sharma, P., 2018. Geology, Structural Architecture and Tectonic Framew ork of the Rocks of Southern Lalitpur District, Uttar Pradesh, India: An Epitome of the Indian Peninsular Shield. Tectonics and Structural Geology: India Context, Springer Geology (Ed. S. Mukherjee): p. 353-379.

Farooqui S.A., Singh A.K., 2006. Platinum mineralization in Ikauna Area, Lalitpur district, Uttar Pradesh. J. Geol. Soc. India, 68, 582-584.

Farooqui S.A., Singh P.K., 2010. PGE Mineralisation in Ultramafic/Mafic enclaves of Ikauna area, Bundelkhand Craton, India. Advances in Geosciences, pp. 111-120.

Geological Survey of India, 2012. Geology and mineral resources of the states of India, Miscellaneous Publication No. 30, PartXIII: Uttar Pradesh and Uttarakhand (Second Revised Edition), 75 p.

Hacket, C.A., 1870. Geology of Gwalior and vicinity. Rec. Geol. Surv. Ind, 3 (2), 33-42.

Heron, A.M., 1935. Synopsis of the Pre-Vindhyan geology of Rajasthan, Rajputana. Trans. Nat. Inst, Sci.,1, 17.

Jhingran, A.G., 1958. The problem of Bundelkhand granites and gneisses. Presidential Address, Proc. Ind. Sci. Cong. 45th session, Madras, 48-120.

Kaur, P., Zeh, A., Chaudhri, N., 2014. Characterisation and U-Pb-Hf record of the 3.55 Ga felsic crust from the Bundelkhand Craton, northern India. Precambrian Research 255, 236-244.

Kaur, P., Zeh, A., Chaudhri, N., Eliyas, N., 2016. Unravelling the record of Archaean crustal evolution of the Bundelkhand Craton, northern India using U-Pb zircon-monazite ages, Lu-Hf isotope systematics, and whole-rock geochemistry of granitoids. Precambrian Research, 281, 384-413.

Medlicott, H.B., 1859. Vindhyan rocks and their associates in Bundelkhand. Mem. Geol. Surv. Ind., II(1), 1-95.

Mishra, R.C., Sharma, R.P., 1975. New data on the geology of Bundelkhand complex of Central India. In: Verma, V.K. et al. (ed.), Recent Research in Geology, 2, 311-346, Hindustan Publishing Co., Delhi-07.

Mondal, M.E.A., Goswami, J.N., Deomurari, M.P., Sharma, K.K., 2002. Ion microprobe ${ }^{207} \mathrm{~Pb} / \mathrm{Pb}{ }^{206}$ ages of Zircons from Bundelkhand massif, northern India, implications for crustal evolution of the Bundelkhand-Aravalli Proto Continent. Precambrian Research, 117, 85-110.

Nasipuri, P., Saha, L., Hangqiang, X., Pati, J.K., Satyanaryanan, M., Sarkar, S., Bhandari, A., Gaur, Y., 2019. Paleoarchean Crustal Evolution of the Bundelkhand Craton, North Central India. In: Earth's Oldest Rocks (Eds.: Van Kranendonk, M., Bennett, V., Hoffmann, E). doi.org/10.1016/B978-0-444-63901-1.00031-9

Pati, J.K., Raju, S., 2001. Petrochemistry of pillowed metabasalts from the Bijawar Group, Central India. Ind. Jour. Geol., 73, 2, 77-92.

Prakash, R., Swarup, P., Srivastava, R.N., 1975. Geology and mineralization in the southern parts of Bundelkhand in Lalitpur district, Uttar Pradesh. Jour. Geol. Soc Ind., 16(2), 143-156.

Ramakrishnan, M., Vaidyanadhan, R., 2010. Geology of India. Journal of Geological Society of India, 556.

Roy, A., Devarajan, M.K. 2000. Appraisal of the stratigraphy and tectonics of the Proterozoic Mahakoshal supracrustal belt, central India: Geological Society of India Special Publication, No. v. 57, p. 79-97.

Saha, L., Frei, D., Gerdes, A., Pati, J.K., Sarkar, S., Patoke, V., Bhandari, A., Nasipuri, P., 2016. Crustal geodynamics from the Archaean Bundelkhand Craton, India: constraints from zircon U-Pb-Hf isotope studies. Geological Magazine 153, $179-192$. 
Sarkar, A., Bhalla, J.K., Bishui, P.K., Gupta, S.N., Srimal, N., 1989. Geochemistry and geochronology of the Early Proterozoic Bundelkhand granitic complex, Central India. Symp. Precamb., Granitoids, Helsinki, Finland, Geol. Surv. Finland, (Abs.), 8, 117.

Sarkar, A., Paul, D.K., Potts, P.J., 1995. Geochronology and geochemistry of the Mid-Archean, Torndhjemitic gneisses from the Bundelkhand Craton, Central India. In: Recent Researches in Geology and Geophysics of the Precambrians (ed.) A.K. Saha, IF: $76-82$.

Sarkar, A., Ghosh, S., Singhsi, R.K., Gupta S.N., 1997. Rb-Sr geochronology of the Dargawan sill: constraint on the age of the type Bijawar sequence of Central India. Intl. Conf. Isotopes in Solar System, (Abs.), 11-14, 100-101.

Saxena, M.N., 1957. Structural study of Bundelkhand granites and associated rocks. India Mining Journal, 5, 9.

Saxena, M.N., 1961. Bundelkhand granites and associated rocks from Kabrai and Mauranipur area of Harnirpur and Jhasi district; U.P., India. Res. Bull. Panjab Univ. 12, 85-107

Sharma, R.P., 1982. Lithostratigraphy, structure and petrology of Bundelkhand Group; In: Geology of Vindhyanchal (eds.: Valdiya, K.S., Bhatia, S.B., Gaur, V.K.) Hindustan Publishing Corporation, 30-46.

Singh, V.K., Slabunov, A., 2015a. The Central Bundelkhand Archaean greenstone complex, Bundelkhand Craton, Central India: geology, composition, and geochronology of supracrustal rocks. International Geology Review 57, 1349-1364, DOI: 10.1080/00206814.2014.919613.

Singh, V.K., Slabunov, A., 2015b. Geochemical characteristics of Banded Iron Formation and Metavolcanics from Babina greenstone belt of the Bundelkhand Craton, Central India. J. of Economic Geol. and Georesource Manage. 10, 63-74.

Singh, V.K., Slabunov, A., 2016. Two types of Archaean supracrustal belts in the Bundelkhand Craton, India: geology, geochemistry, age and implication for craton crustal evolution. J. of the Geological Society of India 88, 539-548.

Slabunov, A.I., Singh, V.K., 2018. Meso-Neoarchaean crustal evolution of the Bundelkhand Craton, Indian Shield: new data from greenstone belts. International Geology Review, doi.org/10.1080/00206814.2018.1512906

Slabunov, A., Singh, V.K., Joshi, K.B., Li, X., 2017. Paleoarchean zircons from quartzite of South Bundelkhand Supracrustal Complex: origin and implications for crustal evolution in Bundelkhand Craton, Central India. Current Sci. 112, 794-801.

Verma, S.K., Verma, S.P., Oliveira, E.P., Singh, V.K., Moreno, J.A., 2016. LA-SF-ICP-MS zircon U-Pb geochronology of granitic rocks from the central Bundelkhand greenstone complex, Bundelkhand craton, India. J. of Asian Earth Sci. 118, 125-137. 